Integritas 3.3 (Spring 2014), pp. 1-18.

doi: $10.6017 /$ integritas.v3iзp1

\title{
Science and the Human Person: Educating for Wisdom
}

\author{
William C. Mattison III
}

Catholic theology both deputizes, and in important ways is accountable to, scientific inquiry. This paper examines examples from the author's experience as a moral theologian, and goes on to explore what this relationship between theology and science suggests for the Catholic university as a whole.

Let me begin by saying a few words of introduction about my own background and scholarship, not by way of apology, or any attempt to establish authority, but rather because I think it exemplifies the main point I want to make, which is this: theology (and philosophy for that matter), and by extension higher education that is rooted in the Catholic tradition, not only should avoid seeing scientific inquiry with suspicion or as a threat, but theology also deputizes and indeed is accountable to such inquiry. Let me say that again. Catholic theology both deputizes, and in important ways is accountable to, scientific inquiry.

During my undergraduate studies at Georgetown I was a double psychology and theology major. My own faith was always a central part of my life, and as an academically inclined young adult I wanted to study that faith in a rigorously intellectual manner, which Georgetown enabled me to do. I was particularly interested in why people do what they do, and thus it is perhaps unsurprising that I was a double major in psychology. Courses like Prof. Steven Sabat's on the neurosciences, and Prof. James Lammiel's on theories of personality, were eye-opening for me. I did my senior research project in psychology with Prof. David Carter (God rest his soul) on the objectivity or subjectivity of people's moralities. In other words, when people make moral assessments, do they

William C. Mattison III is an associate professor of moral theology as well as associate dean of undergraduate studies at the School of Theology and Religious Studies at The Catholic University of America. He received his Ph.D. from the University of Notre Dame for his work on the place of anger in the Thomistic theory of the passions. He is the author of Introducing Moral Theology: True Happiness and the Virtues, and the editor of New Wine, New Wineskins: A Next Generation Reflects on Key Issues in Catholic Moral Theology. 
do so on bases that they believe apply to other people as well, or no? We developed a survey instrument, administered it, and ran it through some regression analysis (I think-it's been a long time!) to determine tendencies and correlations in the responses. In retrospect I'm rather sheepish about all this, and I can only look back in gratitude at Prof. Carter's patience with me for attempting to address such an enormously broad topic. I try to remember this when I hold my students to high standards today.

At this time I also worked at a restaurant called The Tombs in Georgetown. It was working lunches there that I met a man who would become a very formative influence on me in certain ways. Some who have been around Georgetown may know himPhon Hudkins, a retired Department of Labor researcher and self-proclaimed ethologist who has spent the past two decades around Georgetown passing out oddly formatted clippings from recent New York Times and Washington Post articles on the importance of family, rearing patterns, friendship, etc., for the mental and physical health of people. Rooted firmly in an evolutionary biological perspective and himself a non-believer, Phon encouraged me in my theological studies because he was convinced that the guidance of traditional religions like Catholicism was (in most cases) life-giving. But he saw things differently than I. He emphasized the importance of the fourth commandment to honor our parents not as some moral obligation but as a way to sustain the crucial parental bond. Twentieth century psychology and evolutionary biology have only increased our awareness of the importance. Far from concerned with concupiscence or any bourgeois morality, Phon emphasized the importance of the sixth commandment and sexual exclusivity in recognition of both the importance of procreation in human groups and the importance of hormonal changes that accompany sexual activity and enable it to sustain a male-female bond. To me that sounded rather like what the Catholic theological tradition has labeled the procreative and unitive meanings of sex. He extolled the love commandment and friendship, and especially the male-male friendship bond, in recognition of its importance in diminishing aggression and relieving stress. This friendship alerted me to the important points of contact between my interests in moral theology and findings in the evolutionary sciences.

One more biographical point. At Notre Dame when it came time to do a dissertation, I decided I wanted to work on the importance of the emotions for the moral life, and therefore moral theology. I found this topic grossly neglected in the Catholic tradition, or when treated only eyed with suspicion (a situation that only more recently has begun to change). ${ }^{\mathrm{I}}$ I approached my director Professor Jean Porter and told her I wanted to do a dissertation on the role of the emotions in the moral life. Those of you who know Jean will be unsurprised at her wry reply in that classic West Texas accent, “Dear, that's

1 See the three excellent recent books on this topic: Nicholas Lombardo, O.P., The Logic of Desire: Aquinas on the Emotions (Washington, DC: The Catholic University of America Press, 2010); Diana Fritz Cates, Aquinas on the Emotions: A Religious Ethical Inquiry (Washington, DC: Georgetown University Press, 2009); and Robert Miner, Thomas Aquinas on the Passions: A Study of Summa Theologiae I-II 22-48 (Cambridge: Cambridge University Press, 2011). 


\section{To not plumb the riches of the non-theological disciplines that so impinge upon my own work would be ludicrous.}

a life's work not a dissertation." She suggested I look into a dissertation on anger. I left her office dejected. Not only had I been redirected, but the last thing I wanted to do the next two years while writing a dissertation was tell people I was writing on anger. It sounded so, well, angry. Those of you who know Jean will again be unsurprised to hear that she was of course exactly right. An inquiry into anger best enabled me to explore that crucial question of the relationship between the emotions and reason, since anger relies on claims of justice based on instinctual or (God willing in the case of humans) higher cognitive assessments. Though primarily an inquiry into the thought of Thomas Aquinas on anger, the last chapter explored contemporary neuropsychology, and in particular Antonio Damasio's somatic marker hypothesis, to explore how practical decision-making, that quintessentially human activity, is not only influenced by but relies upon emotional responsiveness. ${ }^{2}$

You have now indulged me, and perhaps I have strained your patience in sharing some autobiographical reflections to set up my comments. My point in these remarks is this. So much of what I do as a Catholic moral theologian-human action, anthropology, human development-is not at all uniquely Catholic. To not plumb the riches of the non-theological disciplines that so impinge upon my own work would be ludicrous. To avoid doing so would not impede my work-it would preclude it. Of course I, or moral theologians today, am far from the first to realize this. I'll refrain from any broader inquiry into this over the past two millennia and simply point to Catholic university life in the thirteenth century, that purportedly hegemonically Catholic of eras, as a model for this dynamic in important ways. This was an era of rich engagement with Islamic and Jewish sources. More importantly for us today, it was the era of Albert the Great and the introduction of Aristotle's work into Catholic universities. As much as we might chuckle today at the limitations of Aristotelian biology, it was indeed the most advanced science available to scholastics in western Europe. Albert's work on animals and biology was by far the most extensive to date in Christian Europe. Aquinas, following the Aristotelian appreciation of his teacher and mentor, wrote a treatise on the passions (those embodied movements common to all animals, including human animals) that makes others before it or arguably since pale in comparison. In short, doing theology (and especially moral theology) in a manner deeply informed by the sciences is both essential and well precedented in Catholic higher education.

2 The dissertation is titled Christian Anger? A Contemporary Account of Virtuous Anger in the Thomistic Tradition, Dissertation, University of Notre Dame, 2002. 
That brings us back to the Roundtable title, "Science and the Human Person." I take it that our implicit task here is to reflect on how scientific inquiry, in a manner attentive to the human person, is done well at a Catholic college or university. And by done well I do not simply mean on the terms of the discipline itself, a task I leave to those such as our first two speakers, the biologist Marc Muskavitch and the physicist John Cunningham, S.J. ${ }^{3}$ I mean done in a manner that is integrated with the institution's Catholic mission. More specifically, done in a manner not simply permissible by or compatible with that mission; rather, done in a manner that constitutes an essential part of that mission, without which something would be missing.

I would like to affirm just such a claim about the place of the sciences in Catholic higher education today. I'd first like to rely on my own expertise to address the essential role of the sciences in even theological endeavors. I aim in this first section to demonstrate just how it is that the sciences make contributions that are constitutive of philosophical and theological inquiry, and then use this claim to support the broader claim that the sciences are constitutive of Catholic higher education. Second, I'd like briefly to talk more generally about the relationship between science and other disciplines, and the importance of attending to the whole in Catholic higher education, particularly given what I take to be our charge in Catholic higher education, namely, to inaugurate students into the quest for wisdom. Third and finally, I'd like to address where this does and does not happen in Catholic colleges and universities. There I will identify one way it happens well (which of course could use more support), and another way where we have been struggling.

\section{The Sciences as Source of Accountability in Inquiry into the Human Person}

Why is it that good theological work not only endures but also actually requires good work in the sciences, natural or social? I'll first make some overview comments, and then posit my own research as an example. I am aware that as a moral theologian, my work is particularly amenable to scientific study. After all, a moral theologian examines the impact of theological commitments on how human persons act. And since human action is a more readily observable phenomenon than, say, the immanent relations of the Trinity, it may seem like an easy out to posit research in moral theology to defend the constitutive role the sciences play in theological thinking. I actually suspect our biblical scholar friends would make a similar claim. ${ }^{4}$ I'm quite sure my colleagues in liturgical theology would accept this argument. As for our friends in historical systematic theology, I suspect that they would affirm a version of this claim too, though it would likely require a more precise definition of science, a task to which I will turn below.

3 See Integritas 3.1 and 3.2 (Spring, 2014), respectively.

4 They might remind us how the Genesis 1 seven-day creation account is actually a reflection of "science" in the seventh century BC when it was written. Far from a revealed rival science, the narrative that so-called "creationists" rely upon is actually the contemporary science for this narrative's Priestly authors. See the fine introduction to this by Lawrence Boadt in his Reading the Old Testament (Mahwah, N): Paulist Press, 1984), 114-118. 
If you asked everyone in this room to write down what they imagine to be the most well-known Scholastic dictum, you might get a few agere sequitur esse ("action follows being"), but I suspect the winner would be gratia perficit naturam ("grace perfects nature"). Though most notably diffused by Scholastics, this claim is axiomatic in Catholic theology. It is best understood by noting what it precludes. On the one hand, saying grace perfects nature means that grace does not obliterate nature. The term "perfects" is actually best translated here "completes." So the claim here is that in the graced life, something's natural finality is not erased or deformed, but rather achieved. There is thus continuity between grace and nature. With my students, I often use the resurrected Christ as an example of this claim. After the resurrection, it is still Jesus, the man the disciples knew and loved as they walked the earth together. Resurrected life is indeed continuous with earthly life.

\section{Our understanding of the supernatural is accountable to the natural, since grace perfects, but does not obliterate, nature.}

On the other hand, grace does not just simply achieve natural finality. That is where "perfects" in the English is a better term than "completes." Though grace helps human persons achieve their natural finalities, that natural finality is no longer the ultimate or last finality. The graced supernatural transcends the natural even as it completes it. Though the resurrected Christ is indeed the Jesus the disciples knew, he is not simply that Jesus. He is different, more. He is the glorified Christ, initially not recognized, who appears and disappears, and indeed ultimately ascends.

Now what does all this have to do with science and theology at a Catholic university? Similar to the way that we look at the earthly life of Jesus to learn about the fullness of life to which we have been called, and of which Jesus is the first fruits, the natural can tell us about the supernatural. That's right: you heard that order correctly. The natural informs our understanding of the supernatural. Indeed, our understanding of the supernatural is accountable to the natural, since grace perfects, but does not obliterate, nature. What I'm about to do is draw a parallel between the relationship between nature and grace on the one hand, and the sciences and more obviously mission-driven disciplines at a Catholic university on the other hand. The analogy is not perfect for reasons that will be addressed below. But I claim here it is indeed illuminative. Allow me to cite two brief examples of this dynamic before a more extended example from my own research, and then some summary comments on this first point.

When I was a master's student at Weston Jesuit School of Theology, now part of Boston College, I had a course with Prof. Stephen Pope on love. I chose to do my final paper on what in my field we call "particular relationships." These are those ubiquitous 
natural relationships such as friendships and family relations, be they spousal, parental, or what not. Believe it or not, a perennial question in Christian ethics is how to reconcile these relationships with Christian love or agape, which is unconditional and extends to all, even the enemy and those we do not know. Thomas Aquinas words the question by asking "Whether we ought to love one neighbor more than another?"5 Christian theologians have always recognized, of course, that we do love some more than others. The question is whether this is something we ought to strive to overcome, ${ }^{6}$ or whether this is something to which we ought to acquiesce simply because we can only do so much, and God's providence has put these relations before us.7 Aquinas adopts neither answer. Though of course recognizing we ought to strive to love all, and that God's providence is indeed at work in our special relations, Aquinas claims that the virtue of charity (or love) which comes about through God's grace is no less orderly than our natural relations, "for both inclinations flow from the divine wisdom." ${ }^{8}$ In other words, our special relationships are not mere occasions to be endured as evidence of our fall from grace. Nor are we to participate in them simply because God is using them extrinsically to spread His love. Rather, graced love operates intrinsically through these relations, completing them rather than obliterating them. Charity may elevate these relationships to a life and dignity they could not achieve without God's grace. But that is not to the detriment of their natural finalities, since those are completed. Marriage, parenthood, friendships, and others in the Christian life are indeed elevated. But that higher level to which they are raised is nonetheless in continuity with the nature of those relationships. Therefore, anything we can learn from, say, the sciences about how these relationships function well only helps to illuminate the graced instantiations of these relationships.

Consider a second example, fasting. Since this example is used by my own mentor Jean Porter in her important book Nature as Reason, it provides an opportunity to share her comments on the way that nature has normative force even in the graced realm. When we fast, we allow spiritual goals to shape how we pursue lower, or more immediate goals, such as nutrition. We should note that doing so is not purely a Christian or even religious activity. We commonly allow "higher" goals to shape how we eat, as when we limit eating — or perhaps carbo-load before an athletic event. We might hold off on eating before a performance we are nervous about. We commonly fast for medical reasons, before tests or surgery. Thus the dynamic of further, or "higher," goals shaping how more immediate ones are done is not limited to a religious context.

But back to fasting. We fast not out of any rejection of food or whatever it is we give up, but to remind ourselves of our seemingly less immediate, but in actuality our far more important needs and desires and yearnings, namely, for God. Here grace

5 Thomas Aquinas, Summa Theologiae II-II 26,6 [henceforth ST].

6 For an example of such relationships as impediments to true Christian love or agape, see Anders Nygren, Agape and Eros, trans. Philip Watson (London: SPCK, 1953).

7 Augustine, Teaching Christianity (New York: New City Press, 1996), i.28.29.

8 Thomas Aquinas, ST II-II 26,6. 
transcends nature. Yet it also completes it. Though the immediate goals of nourishment are placed in broader perspective, those immediate goals should still be met. In other words, fasting should not harm bodily health. Aquinas credits even the cantankerous and austere St. Jerome with the claim that we must not "afflict the body immoderately." Near this attribution to St. Jerome, Aquinas explains the dynamic in play by saying:

Now reason judges it expedient, on account of some special motive, for a man to take less food than would be becoming to him under ordinary circumstances, for instance in order to avoid sickness, or in order to perform certain bodily works with greater ease: and much more does reason direct this to the avoidance of spiritual evils and the pursuit of spiritual goods. Yet reason does not retrench so much from one's food as to refuse nature its necessary support. ${ }^{9}$

Aquinas elsewhere says though we commonly refer the activities of temperance to further ends such as eternal salvation, its immediate goal pertains to the purposes of this life. ${ }^{\text {I }}$

Discussing the related question of the relationship between acquired (i.e., natural) virtues and infused (i.e., graced) virtues, Porter claims "the acquired virtues, considered as ideals stemming from human nature, provide...a set of parameters in terms of which the ideals of the infused virtues can be articulated." "II She then words it even more starkly: "the natural law informs the infused virtues." ${ }^{2}$ This is an extraordinary claim, namely, that the so-called "higher" goals might be in important ways accountable to the "lower" or more immediate ones. As Porter concludes pages later, "for Aquinas the exigencies and inclinations of human nature, generally considered, are not simply obviated by grace or subsumed under its imperatives. They continue to exercise normative force, even over against what might be regarded as spiritual aims." ${ }^{\text {13 }}$

Having set up the conceptual apparatus of how the dynamics and finalities of nature persist in the realm of grace, let's turn to a third and final example from my research on the passions. In this example we do not address a nature/grace example per se, but

$9 \quad$ II-II 147,1 ad 2.

10 II-II 141,6 ad 1.

11 Jean Porter, Nature as Reason (Grand Rapids, MI: Eerdman's, 2005), 389. Ellipsis stands in for the phrase "both a point of contrast and." I omitted it to focus on the relevant point here. To elaborate further on the point of contrast would require more discussion of the difference in formal object between acquired and infused virtue (see I-II 63,4), a topic beyond the scope of this paper but also not evidence to the contrary of this paper's point. Porter, Nature as Reason, 389.

13 Porter, Nature as Reason, 394. Admittedly, "what might be regarded" does significant work here, as the claim is not that any perceived natural end exerts normative force on the supernatural end at hand. The quote continues: "This point is sometimes obscured by language of higher and lower aims and inclinations; the hierarchical ordering of human inclinations does not imply that the needs stemming from more basic inclinations should always give way....At any rate, it is the human person considered as a whole, in all her complex and interrelated needs and inclinations, who exercises moral demands on herself and others. These demands inform the virtues in complex ways that cannot be reduced to simple rules of priority and precedence among the inclinations" (394-5). 
rather a comparable case where the more immediate finalities of sciences inform and hold accountable the "broader," if you will, finalities of philosophical anthropology (and of course ultimately theological anthropology). Though I'd argue this example is thoroughly Thomistic, it extends beyond Thomas's explicit thought.

As I learned during that dissertation research, Thomas makes two explicit claims that stand in some degree of tension. First, the passions or emotions participate in reason and will. Rather than being merely reined in (or on occasion "released") by higher powers, they participate in those higher powers. Reason and will penetrate and permeate the passions, such that our emotions themselves (and not just acts ensuing from them) can be praiseworthy or blameworthy. Indeed, Aquinas claims the passions can be subjects, or seats, of virtue (or vice for that matter). Despite the fact that our embodied, instinctridden emotional responses are a facet of our anthropology we share with animals bereft of reasoning ability, Aquinas claims in the human person they can be fully humanized because they participate in reason.

Yet with this claim Aquinas also holds that the passions are humanized, and thus morally evaluable, only when commanded by reason and will. He even employs certain descriptors and distinctions that suggest the relationship is chronological. ${ }^{\mathrm{I4}}$ Emotions that proceed from reason and will (whether good or bad) are fully human and morally evaluable. To use a stock Thomistic example, is it more or less praiseworthy to give alms with feelings of empathy? Thomas claims it depends. If the empathy is antecedent to reason and will such that we are acting "out of emotion" rather than from understanding and choice, the emotion diminishes the moral goodness of almsgiving. However, if our empathy proceeds from reason and will, in other words if our grasp and choice of an act engenders empathy, that emotion increases the praiseworthiness of the act, since Thomas, citing Psalm 83:3 that "my heart and my flesh have rejoiced in the living God," says it is fitting to do the good not only with the higher powers but also the emotions. In the Christian tradition (and indeed Western tradition), this is actually a very positive and prominent place for the emotions in the moral life. Yet though this does recognize the important role of the emotions in the moral life, insistence on the chronological priority of reason and will seems to rob the emotions of that spontaneity and "short-cutting around deliberation" that make them so wonderful (and frustrating) in our lives, and

14 See Thomas Aquinas, ST I-II 24,3 ad 1 on the antecedent / consequent distinction with regard to the morality of the emotions: "The passions of the soul may stand in a twofold relation to the judgment of reason. First, antecedently: and thus, since they obscure the judgment of reason, on which the goodness of the moral act depends, they diminish the goodness of the act; for it is more praiseworthy to do a work of charity from the judgment of reason than from the mere passion of pity. In the second place, consequently: and this in two ways. First, by way of redundance: because, to wit, when the higher part of the soul is intensely moved to anything, the lower part also follows that movement: and thus the passion that results in consequence, in the sensitive appetite, is a sign of the intensity of the will, and so indicates greater moral goodness. Secondly, by way of choice; when, to wit, a man, by the judgment of his reason, chooses to be affected by a passion in order to work more promptly with the co-operation of the sensitive appetite. And thus a passion of the soul increases the goodness of an action." 
indeed which ethologists tell us make them from an evolutionary perspective so effective in terms of aiding survival.

It was in turning to recent neuroscientific research on the emotions that I found both the basis to challenge Thomas's chronological claims regarding the priority of reason to emotion, and also the resources for improving it. In a series of case studies of famous (and mercifully rare) patients who suffer brain damage to the limbic system (center of emotional activity) yet who maintain full capacities in the distinctively human pre-frontal cortex (center of higher reasoning), Antonio Damasio demonstrates that proper emotional functioning entailing the limbic system is not simply important to keep emotions under control and out of the way so we can reason clearly and make good choices. Absence of emotional capacity actually prevents proper practical decisionmaking. Contrary to the caricature of the Kantian ideal moral agent who is able to think rationally and execute one's duty shorn of any adulterating emotional influence, Damasio's case studies of the rare real-life people who function in this way reveal that they, far from model moral agents, are in actuality morally incapacitated. One can conclude from his work that while it is indeed "higher" reasoning ability that makes human persons all they are, "lower" powers - in this case the emotions-are not merely connected to that higher functioning in an accidental manner. Rather, they are constitutive of the proper functioning of that higher reasoning. Contra the chronological read of Thomas's words on the relationship between passions and reason where fully humanized passions occur only when reason and will precede and deputize them, Damasio through his "somatic marker hypothesis" shows that in important ways emotional responses are required for practical reasoning. ${ }^{15}$ How to respect the contributions of the neurosciences on the emotions, and still employ the many insights of Aquinas on the emotions, is a task that is occurring in contemporary scholarship, though one beyond the scope of this essay. ${ }^{\mathrm{I}}$ Such accountability to the sciences must occur. And I actually think there are insights in Thomas's work about the logical (if not chronological) priority of reason and will that are required to most accurately apply Damasio's work. As Christian ethicist Jim Gustafson would say referencing the title of a book he wrote, there are genuine intersections here,

15 See Antonio Damasio, Descartes' Error: Emotions, Reason, and the Human Brain (G.P. Putnam's Sons, 1994).

16 See William C. Mattison III, "Explaining the Role of Emotions in the Moral Life: Thomas Aquinas and Neuropsychology," pp. 277-292 in Michael H. Barnes (ed.) Theology and the Social Sciences: Annual Volume 46 of the College Theology Society (New York: Orbis, 2000); Giuseppe Butera, "On Reason's Control of the Passions in Aquinas's Theory of Temperance," Mediaeval Studies 68 (2006): 133-60; Giuseppe Butera, Thomas Aquinas on Reason's Control of the Passions in the Virtue of Temperance, Ph.D. dissertation, The Catholic University of America, Washington, D.C., 2001; Paul Gondreau, "The Passions and the Moral Life: Appreciating the Originality of Aquinas," The Thomist 71 (2007): 419-450; Nicholas Lombardo, The Logic of Desire (Washington, D.C.: The Catholic University of America Press, 2010); Servais Pinckaers, O.P., "Re-Appropriating Aquinas's Account of the Passions," in Berkman and Titus (eds.) The Pinckaers Reader: Renewing Thomistic Moral Theology (Washington, D.C.: The Catholic University of America Press, 2005), pp. 273-287; Craig Steven Titus, "Passions in Christ: Spontaneity, Development, and Virtue," The Thomist 73 (2009): 53-87. 
and the traffic travels both ways. ${ }^{17}$

Though Thomas's work requires emendation here due to contributions of the sciences, I would argue his language of the relationship between passions and reason is helpful not only for his purposes but for our own today. He claims the passions participate in reason. What does he mean by this claim? Our friends here who teach Catholic Social Teaching know about the principle of participation. And Thomas uses a political metaphor to describe this relationship. He claims that the passions are not simply ruled despotically by the higher powers, that is, treated as slaves. Rather, they are ruled "politically," such that even while governed they retain "something of their own." 18 This language of participation (rather than control) is crucial. Though perhaps the most extensive literature on the notion of participation is in the field of metaphysics, it is also a political language that can help us understand the proper relationship between different parts of something whole. More on that in the following section.

Before turning to that section a word is in order on the above examples. I started with examples taken from the relationship between nature and grace. There we saw that even the "higher" realm of the supernatural is accountable to an accurate understanding of the natural. The natural is continuous with grace, and as such its finalities are constitutive of the broader finalities of the supernatural. Indeed, we could also further explore how inquiry in the natural realm becomes a locus for exposure to and inauguration into the supernatural, which has ramifications for how we understand evangelization to occur at our Catholic institutions of higher education.

Yet note that in the final example about the passions participating in reason, the dynamic is not one of nature and grace, since the question of the passions' participation in reason, though informed by theological commitments, is not properly one of theology but philosophy. Thus the dynamic of the proper relationship between "higher" and "lower" addressed above, while helpfully illuminated by nature and grace, is more broadly a dynamic of participation whereby the distinct levels of finality are related to one another in an intrinsic, common good manner, rather than in an extrinsic or instrumentalizing manner. This is addressed in my next section.

\section{The Quest for the Whole in Catholic Higher Education}

What this last example makes clear is that the empirically based sciences-be they natural or social—cannot be run over roughshod by the so-called higher disciplines of theology or philosophy. Even when questions about finality are not simply matters subject to empirical inquiry and verification, they nonetheless concern such matters. There is continuity between the subject matter of the sciences and that of philosophy and theology, and such continuity renders the latter accountable to the former. This accountability is evident even in the relationship between nature and grace, where grace

17 See James Gustafson, Intersections: Science, Theology, and Ethics (Pilgrim Press, 1996). I raise up this work simply as an example of how the sciences can play a constitutive role in a discipline such as philosophy and ultimately theology. 
perfects nature but nonetheless is continuous with it and therefore accountable to it. Grace respects the finality of nature, even as it integrates it into a whole that transcends the finality of nature. We have seen that there are foundational Catholic theological commitments affirmed in the claim, having to do with the common origin (and even ultimate-though supernatural-destiny) of the natural and the graced. Both flow from the divine wisdom. Thus the philosophical and theological endeavors to better understand the human person not only condone, but necessitate, scientific inquiry when the sciences help us better understand the human person.

In the above there is repeated reference to higher and lower, or more immediate and further goals. This language is particularly useful in analyses of goal-oriented activity, since I take it as given (as did Aquinas, Aristotle, and so many others) that we humans are intentional, or goal-oriented creatures. Though of course at times unreflectively, or even incoherently, we pursue more immediate goals in light of further goals, and these further goals inform how we pursue the immediate ones. This is the realm of pursuing the good, ultimately pursuing happiness. It might be objected that we are drawing an illegitimate analogy between the relationship between "higher" and "lower" in goaldirected activity on the one hand, and in the acquisition of knowledge on the other. To claim the sciences are "lower" or "more immediate" branches of knowledge might seem at the least insulting, and more importantly inaccurate. After all, scientists are commonly the most brilliant among us. Furthermore, all forms of knowing are apprehensions of the subject matter at hand, be it as immediate as liquid viscosity in varying environments (a topic in which we excel at Catholic University) or as transcendent as being or even God's very Self. Knowledge is knowledge, and is an end in itself, this objection might continue. Indeed, it may seem at this point all that has been said is a setup for the old fashioned claim that theology is the "Queen of the Sciences."

There is certainly no claim here as to the relative intelligence of natural and social scientists on the one hand and philosophers and theologians on the other. I would also say that calling certain forms of knowledge "higher" on the basis of subject matter is not even a claim about the relative importance of them at any university. Nonetheless, I am indeed claiming that different branches of knowledge attend to their subject matters in manners appropriate to their methodologies, and these methodologies are reflective of the scope of the immediate inquiry.

Consider some examples. The biologist studies muscle tissue, cancer cells, and enzymes. Not due to the physical size, but to the accessibility of this subject matter to empirical verification and even manipulation, ${ }^{19}$ the scope of biology is more immediate. This is true even if, of course, the ramifications of its findings at this scope are earth-shattering. One need only think of advances in cloning, or penicillin, to see such reverberations. Again, the present claim about scope is not one of importance. The history or literature scholar examines historical data or the pieces of literature, a

19 By manipulation I mean not in a pejorative sense but in a laboratory sense of what can be handled and arranged and changed with our hands, even if "hands" is often figurative. 
methodology that requires at times a rather immediate scope but which also properly makes claims about historical causality and authorial intent, matters less amenable (though not at all hermetically sealed from) empirical verification and manipulation. The philosopher might explore how knowledge is attained or how various forms of knowing are related to one another (such as we are doing here), matters again not untethered to rational analysis but which are even more removed (though not at all unconnected) from empirical verification and manipulation. A theologian might explore how God's grace transforms human activity, and how something like the Eucharist is an agent of that transformation. Though even further beyond empirical verification, the findings of sociology on ritual, and neuroscience on human action, are not only related to such inquiry but constitutive of it.

Though the varying disciplines have different scopes of
inquiry and different methodologies, they require one
another for a full understanding of the topic at hand, all the
more so when the subject of inquiry is something as broad as
the title of this Roundtable, "the human person."

Theology's subject matter is indeed that which is most beyond (though again of course not unconnected to) empirical verification and manipulation, and therefore in that sense a "higher" discipline. In fact, philosophy is right there with it, given that its subject matter includes being itself in metaphysics, though theology embarks on that inquiry with revelation as a further resource. However, this does not mean that theology (or philosophy) can do without the sciences while the latter cannot do without theology or philosophy. Indeed, the entire start of this essay is a case for the accountability of theology, whose proper object is the supernatural, to the sciences (among other disciplines), whose object is the empirically verifiable natural. Though the varying disciplines have different scopes of inquiry and different methodologies, they require one another for a full understanding of the topic at hand, all the more so when the subject of inquiry is something as broad as the title of this Roundtable, "the human person." Though the varying disciplines approach that subject matter on a variety of levels with a variety of methodologies, a complete understanding of a complex subject matter like the human person requires the cooperation, even again mutual accountability, of the disciplines.

What is necessary to achieve this comprehensive, integrated inquiry into a topic such as the human person (we could have also said the social order, the transcendent, etc.) is an accurate recognition of the scope of the distinct disciplines, both to acknowledge each one's distinctive contribution to the overall inquiry and, perhaps as importantly, to properly delineate the scope of each discipline. There are few things worse than 
theologians or philosophers asserting authority in matters of scientific inquiry. Of course it is also the case that scientists should recognize the proper limits of their own expertise and authority. In the same way that a discipline like theology is accountable to the findings of the sciences, scientists (and indeed scholars in other disciplines) should recognize when they make claims about their findings that transcend the direct conclusions of their findings. There are people in the room far better qualified than I to speak from experience about the step from data to hypothesis and interpretation of data, and the even larger step of theorizing based on that data. Indeed since the work of Thomas Kuhn we have become aware of the extent to which, even in the sciences, paradigms shape the interpretation and presentation of data. ${ }^{20}$ There is nothing at all wrong with this. If the more immediately empirically verifiable findings did not have any broader ramifications we would likely not do the research at hand. But in the same way that a theologian must acknowledge (and be open to revising) the more empirically verifiable assumptions in her inquiry that are required by that inquiry but not within the direct scope of the researcher's discipline, the scientist while positing conclusions rooted in data must also acknowledge that extension beyond the proper scope of scientific inquiry and be open to alternate interpretation of the data at hand (to which any interpretation must indeed be accountable). None of this reflection on the proper purview of the sciences and of philosophy and theology is new. People like my former teacher at Georgetown, Prof. John Haught, among others, have been beating this drum for decades. But it is surprising that these insights too infrequently inform our understanding of the relationships between, limitations of, and mutual accountability of the disciplines at a Catholic university where the ultimate goal of a liberal arts education is wisdom. It is education not only of the whole person, but of the human person for the whole. And at Catholic universities and colleges, reflection on the whole is not simply a philosophical endeavor, but also a theological endeavor given what our faith tells us is true of the whole.

\section{What should be evident in these comments is a sort of common good vision of the relationship between disciplines.}

What should be evident in these comments is a sort of common good vision of the relationship between disciplines. Each flourishes only in proper relation to the rest. What vision of the human person can be complete without attention to literature, poetry, and visual art? How can we understand who we are without a grasp of the biology, chemistry, and physics of ourselves and the world which we not only inhabit but to which we belong? How can we not employ mathematics, statistical analysis, and experimentation to better grasp our placement in the ecosystem? And what human life 
is complete without attention to ultimate questions about ourselves and especially the transcendent? In the final section of this paper I turn to examine how such integration does and does not happen at Catholic colleges and universities.

\section{Finding the Whole (or Not) in Catholic Higher Education}

In light of the Roundtable theme of science and the human person, this essay has endeavored to examine the role of the sciences in understanding the human person in the context of Catholic higher education. I first attempted to explain why-in a manner reflective of Catholic theological commitments such as the claim that grace perfects nature-the sciences ought not merely be permitted or condoned in the mission of Catholic higher education. To the contrary, scientific inquiry is essential to an adequate understanding of the human person. Something is missing without it, much as something is lacking when there is not attention to philosophy and theology in higher education. But the claim here is not simply that the sciences offer something that the humanities do not, a claim I take to be uncontested and bland. The stronger claim here is that other disciplines - and as a theologian I have focused on that one-are accountable to the sciences in their own functioning. They are not merely accidentally related to one another as discrete vehicles for apprehending truth (though they are that too). Much as political theory recognizes two basic, rival accounts of the social order as either a contract or a common good, where the former regards the flourishing of individuals as related to that of others but only accidentally and the latter regards that relationship more intrinsically, I am claiming here that such an intrinsic relationship exists between the sciences and theology among other disciplines.

The question for this section is, where is that integration evident on our campuses? Do students graduate with a sense of this integration? Professor Kevin Hughes reminded us at the last Roundtable that while the acquisition of skills is a crucial part of our institutions' missions, a characteristic feature of Catholic higher education is growth in wisdom, not simply acquisition of skill, or techne. ${ }^{21}$ Though both entail a growth in truth, the latter is an accurate apprehension about things to be done while the former is an accurate apprehension about the whole of how things are. This is of course true not only at Catholic schools but in all truly liberal arts institutions, though at Catholic schools that wisdom is regarded as most fully manifest, indeed revealed, in the Word made flesh. How do we inaugurate students into the quest for wisdom? That is the question of this section, and should be the question of all Catholic higher education. Obviously this is an enormously broad topic that cannot be done with anything near completion here, but I will suggest two ways this can and should occur on our campuses.

\section{The Researcher as Human Person}

First, it occurs in the human person. In our discussion today of science and the human person I have been addressing the human person as the object (or topic) of study if you

21 Kevin L. Hughes, "Response to Thomas G. Plante," Integritas 2.1 (Fall 2013). 
will. ${ }^{22}$ In order to have an adequate understanding of such a rich and complex object of study as the human person, we require a multitude of disciplines mutually informing each other. Thus the sciences help us better understand who the human person is. But of course it is also a human person as subject who engages in scientific study. ${ }^{23}$ In other words, the scientist on campus is him- or herself a human person who engages in research.

Though serving at a university as a scientist, a science professor is not simply a person who engages in scientific inquiry. She is a human person herself, whose research and scientific inquiry is integrated in her person. Beyond the immediate activity of her research she models to her students in the lab and in the classroom the integration of that activity with other arenas of inquiry. Her expertise is the science, but as a human person she is not and cannot be limited to the conclusions of her scientific methodology. This is why-though philosophers and theologians may lament it-it is understandable and possibly unavoidable for scientists to address the ramifications of their work to questions beyond the proper purview of their discipline. Our students witness this in their professors of science, God willing. And I do not mean simply the ways that scientists attend to the ethical limitations on their research, though that is important. Or even the ways that scientists treat one another and students in performing that research, though again that is important. I mean their integration of their findings into an overall quest for wisdom of which their findings form a constitutive part. I offer two examples.

I mentioned my friend Phon earlier, an ethologist non-believer who appreciates the Catholic tradition for how so much of its moral vision is ethologically sound and leads to physical health and flourishing. Phon will commonly make jumps from the area of his expertise (stress diseases, results of rearing patterns, etc.) to claims about gender or God, for instance. I probably disagree with those jumps as often as I agree with them, and at times it is maddening. But it is completely reasonable that he makes such jumps. As a person who is not just an ethologist, but a seeker of wisdom, indeed it would be odd if he did not attend to the broader ramifications of this research.

I think here also of perhaps my favorite teacher at Georgetown, Professor Steven Sabat. He taught me, in addition to Introduction to Psychology, a course on the neurosciences. We learned especially about his work with the elderly, people whose neurological function is in decline, or at times why it wasn't. His work in that area seemed top notch. But the reason why he was such an impact on me was the way he integrated that work into his understanding of the beauty and dignity of the human person. Sabat is a Jew, and therefore to use John Paul II's term, one of our big brothers in the faith. I have no idea of his faith practices, but I can say he was one of the most important influences on me in terms of Catholic higher education. He modeled the integration of academic expertise and the search for wisdom. He was accountable to his findings of course. But

22 I mean object not as in objectified, but as in topic of study.

23 I mean subject not as used in a psychological experiment, but rather subject as in agent. 


\section{Personal encounters are not mere window dressing for higher education. They are a crucial vehicle of knowledge.}

he also witnessed an accountability to science that nonetheless avoided reducing all bigger questions to the findings of the sciences. I never at Georgetown had a course or explanation of how the various disciplines are inextricably bound. But I witnessed it in persons like Steven Sabat (or Phon Hudkins, or John Haught).

As I addressed at the last Roundtable, personal encounters are not mere window dressing for higher education. They are a crucial vehicle of knowledge. So thank God in all of our institutions, encounters between students and professors like Sabat can and do model the sort of integration and coherence I outline in this essay. Those relationships are therefore an invaluable vehicle for teaching toward wisdom. That said, they would be aided if we more explicitly addressed that coherence. And so I turn to a second way to inaugurate students into the quest for wisdom, a way where we have great room for improvement.

\section{The Curriculum}

Core curriculum; general education requirements; distribution requirements; or whatever you wish to use (and there are not insignificant differences in these)-these are the ways that we attempt to instantiate our increasingly inchoate sense that a liberal arts education is there not just to establish competencies, or train people in a major, or allow students unfettered (and consumeristic) choice to pursue whatever interests them. We have a responsibility to educate students broadly.

But in wording it this way there is a sense I have already "mailed it in." To base this responsibility simply on an obligation to diversity or breadth-be it in cultures or disciplines or competencies - is in some sense to have already ceded the true goal (I would argue) of this inchoate sense. That true goal is to inaugurate students into the quest for wisdom. Wisdom attends to the whole, and the whole in a manner attentive to all of the constituent parts. Beyond the well-documented difficulties over the past several decades of naming any "canon" of texts that all students should be taught, colleges and universities-including Catholic ones-have been increasingly UN-able to articulate even the rationale for general education requirements, which I am suggesting is an ushering of students along the path to wisdom. So unsurprisingly, and many in this room know this in a far more detailed fashion than I, general education requirements have been reduced, or in some notable cases eliminated. When they do remain, the rationale given is generally to give students some exposure to breadth or diversity, or to equip students with a set of competencies. But the lack of any more substantive basis for such requirements leaves us in a situation akin to Alasdair MacIntyre's famous After Virtue thought experiment, with remnant shards of general education requirements experienced today as incomprehensible taboos without any 
more coherent rationale. This leaves many wondering if such requirements are at times more about academic department turf protection, which results in students engaging in box-checking class selection (usually on the basis of schedule) to cover an incoherent distribution requirement.

Before this turns into too much of a rant, many students will always perceive requirements as extrinsically imposed obligations, and will choose on the basis of schedule. I grant this. But as someone who advises 70 undergraduate theology majors, the lack of a rationale for general education requirements makes it tough to lead them beyond these practices on the basis of anything other than well-reviewed professors. The rationales most commonly offered are, as noted, on the basis of diversity or breadth on the one hand or the cultivation of competencies or skills on the other. In a recent article on the death of the core at Harvard, new Program in General Education Associate Director Anne Marie Calareso is quoted as saying the new program's goal is "linking the arts and sciences with the twenty-first century world." ${ }^{24}$ The article goes on to say the program is intended to equip students with skills to process information rather than a specific body of knowledge. On the main page of this program there is no mention at all of how the eight "categories" from which each student must take one course are related to one another. ${ }^{25}$

In fairness to Harvard, we do not have any articulated rationale for how our required courses at Catholic University constitute some sort of coherence either. At Catholic we have one of, if not the, heaviest set of distribution requirements in the country, fully 20 extra-major courses, including four theology \& religious studies, four philosophy, four math \& natural science, four social \& behavioral science, three humanities, three composition and literature, and two language. ${ }^{26}$ The distribution is exactly half of one's degree. Now at this point it remains organized on the basis of content and derivatively discipline, but no rationale for its coherence is given.

Unsurprisingly, professors are clamoring for a reduction of that number of requirements, and you know that theology and philosophy are particularly high-value targets. In fact, our School of Arts \& Sciences has released a committee proposal on a new set of general education requirements. Though not the same as the Harvard program, our proposal's influence by that program is evident. It reduces the required theology and philosophy courses to three each and replaces all else with five "minds" and four "competencies," with possible limited "double-counting" among these aforementioned categories. The lack of explanation of the relationship of these to one another, or how they constitute a coherent whole, is as evident as the Harvard program.

Clearly my point so far has been that there must be some rationale for general

24 Sabrina Mohamed, "Ding Dong the Core is Dead," Harvard Crimson May 24, 2012: http://www. thecrimson.com/article/2012/5/24/gen-ed-value-questioned/?page=1, accessed March 21, 2014.

25 http://www.generaleducation.fas.harvard.edu/icb/icb.do.

26 I know that is 24 but I say 20 since any major falls into one of these and those four courses are "covered" by major requirements. 
education requirements, and it should be one that is based on a quest for wisdom, which requires some attention to the whole and how various constituent parts are related to the whole. Now this need not be to the exclusion of skills or competencies. It certainly need not discourage innovative teaching practices such as online education or flipped classrooms. ${ }^{27}$ And there is no reason that, say, a non-Western requirement could not be situated within a coherent content-based curriculum. But when core education requirements are reduced to simply exposing students to diversity, equipping them with skills, or maximizing choice, we have failed in the obligation of liberal arts education (and especially Catholic liberal arts education) to usher students along the path toward wisdom.

\section{Conclusion}

In summary, the main points of this essay are the following. First, particularly in topics as rich as the "human person," the various disciplines and their corresponding methodologies are best understood as providing essential contributions to the overall endeavor and holding the other avenues of inquiry accountable in important ways. Each has a contribution to make within its own proper purview, a contribution not accidentally related but intrinsically related to the other disciplines' inquiry. Second, it is in the context of a quest for the whole, a quest for wisdom, that the proper relationship between these avenues of inquiry is understood. In that context there is admittedly some privileging of theology and philosophy as most closely oriented toward that whole as a topic of study. That said, as should be evident after section one and some reflection on the notion of participation, the relationship among disciplines is best understood in the manner of a common good, where the flourishing of any one part is intrinsically connected to the flourishing of other parts. Where is that flourishing witnessed today in Catholic higher education? This was the question of section three, which offered two answers. It is thankfully perhaps most evident in individual persons of wisdom on our campuses who mentor and inspire our students. Most of us are likely in this field due to such people who mentored and inspired us. But it should also be evident in the courses of study on which we lead our students. On this I fear we fare rather poorly. One of the key ways we can move toward rectifying that lack is through richer understanding of how varying disciplines, including the sciences, are constitutive of the quest for wisdom at Catholic institutions of higher education, including inquiry into topics as rich as the human person.

27 Surprisingly, the encouragement of such pedagogical innovation is the most common reason given in the above Crimson article for the new program. Yet it is unclear why such methods could not be employed in a more content-based curriculum. 